\title{
Sediment Characteristics of the Andoni Flats, Niger Delta, Nigeria
}

\author{
*11ANSA, EJ; ${ }^{2}$ FRANCIS, A \\ *I African Regional Aquaculture Centre/Nigerian Institute for Oceanography and Marine Research, P.M.B. 5122, Port Harcourt, Nigeria. \\ ${ }^{2}$ Dept of Animal Science and Fisheries, University of Port Harcourt, P.M.B. 5323, Port Harcourt, Nigeria. \\ Email:ebi_jo@yahoo.com
}

\begin{abstract}
A baseline study of the intertidal and subtidal zones of the Andoni flats was conducted to determine the basic physical and chemical characteristics of the sediment. Sediment characteristics revealed sandy to loamy (muddy) sand soils with $\mathrm{pH}$ of 4.09 to 5.04 . Values of organic carbon varied from $0.17 \%$ in the sandy soil to $3.01 \%$ in the muddy sand soil. Other parameters determined include organic matter which varied between $0.29 \%$ and $5.22 \%$, conductivity with values varying from $1120 \mu \mathrm{Scm}^{-1}$ to $1800 \mu \mathrm{Scm}^{-1}$ and water absorbency with values ranging from $21.74 \%$ to $43.73 \%$. Particle density, bulk density and porosity of the sediment were also determined for the flats. @.JASEM
\end{abstract}

The physical and chemical characteristics of any water body are of ecological significance especially in estuarine ecosystems that are prone to daily tidal physicochemical fluctuations. Studies on basic physicochemical characteristics carried out in various rivers, lagoons and estuaries in Nigeria have focused on the water quality parameters of the rivers' water columns (Akpan and Offem, 1993; Akpan, 1999; Ajao and Fagade, 2002; Akpan et al, 2003; Ekeh and Sikoki, 2003; Francis 2003; Edokpayi et al, 2004): with little or no consideration given to the bottom or sediment characteristics. Unfortunately, river or lagoon beds which are ideal habitats for several species of organisms usually serve as a 'sink' for both domestic and industrial wastes from anthropogenic activities. Dumping of such wastes could alter the ecological state of these ecosystems. Hence baseline studies are required to determine the status of sediment structure and quality to give complimentary data on the physicochemical characteristics of these habitats. Lie (1968) and Sankare et al (1997) in separate studies, recorded different substrate types occurring in the Puget Sound and Tendo Lagoon respectively.

The Andoni flat is a sensitive ecological zone and an integral part of the Andoni River system. The estuary is exposed to both natural environmental factors and human exploitation activities on a daily basis. This paper describes the sediment structure and the physicochemical characteristics of the interstitial fluid in the Andoni flat. This will provide baseline information which could be used as a reference in time of impact on the environment.

\section{MATERIALS AND METHODS}

Study Area: The study area is located in the intertidal zone of the Andoni flats and lies on latitude $4^{\circ} 34^{\prime} \mathrm{N}$ and longitude $7^{\circ} 22^{\prime}$ to $7^{\circ} 23^{\prime} \mathrm{E}$ (Fig. 1). The intertidal zone of the flats has a vast expanse of mud and sand that is exposed to aerial conditions for several hours due to daily tidal cycles. The exposure to aerial conditions facilitates the process of cultivation of the bloody cockle Senilia (=Anadara) senilis by natives which is a major activity in the area and means of livelihood for several families. There is a fringe of vegetation comprising red mangrove Rhizophora $\mathrm{sp}$ and the nipa palm Nypa fruticans bordering the edge of the flats. Four stations in the area were sampled. Station I located on the same side of the Ika fish market at the high water of neap tide in the intertidal zone; Station II bordered by mangrove vegetation (Rhizophora sp and Nypa fruticans) in the intertidal zone; Station III at the low water of neap tide in the intertidal zone and Station IV located in the subtidal zone.

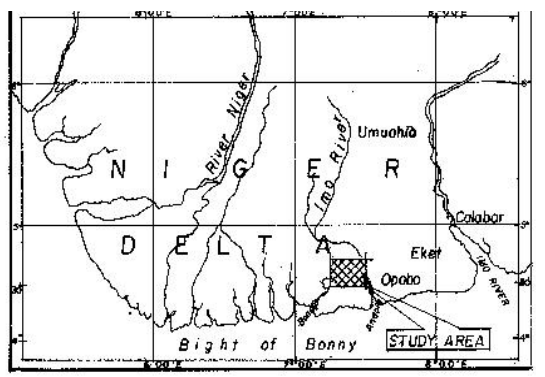

*Correspondence: E-mail: ebi_jo@yahoo.com 


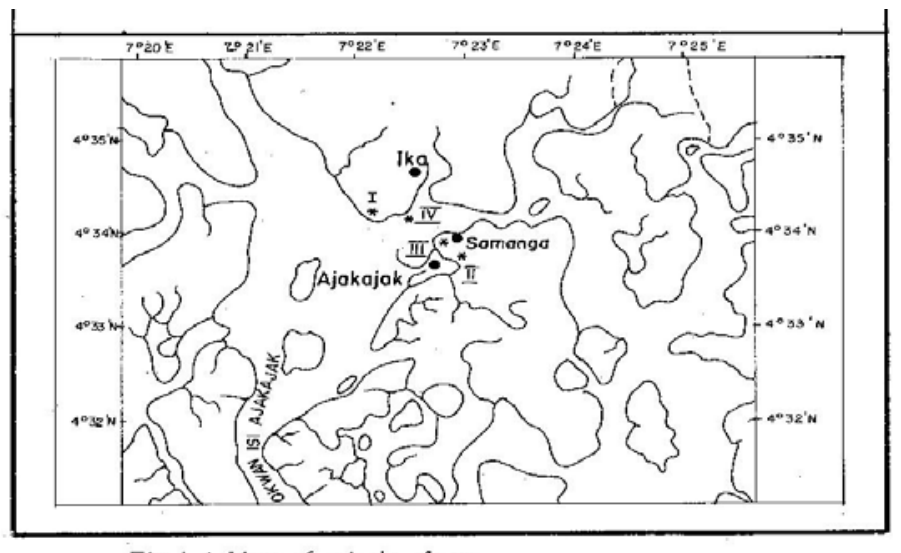

Fig. 1 : Map of study Area

Sampling: Cores and cylinders were used to collect representative soil samples from the stations. The samples for each station was then placed separately in labeled polyethylene bags and transported to the laboratory for analysis.

Laboratory Analysis: The particle size of sediment was analysed using the hydrometer method (Bouyoucos, 1951). The particles of the soil were separated by gravitational sedimentation and a hydrometer used to determine the concentration of suspended solids in grams per litre (g. $\left.\mathrm{l}^{-1}\right)$. To determine water absorbency of the sediments, samples were oven-dried and crushed in a mortar using pestle. Thereafter $3 \mathrm{~g}$ of sub-sample was weighed, soaked in water for 24 hours, excess water was drained and the sample reweighed (Smith, 1996). The particle density and bulk density of sediment were determined according to methods in Blake (1965 a, b) using a mass balance and cylinder. Labeled cylinders of predetermined volumes and weights were used to collect sediments from sampling stations. The soil within the cylinders was held intact and taken to the laboratory for analysis. The soil-in-cylinder was then oven dried till constant weight was achieved. Thereafter, oven-dry soil volume and weight were determined. Values obtained were then used as inputs for the equations viz:

$$
\text { Particldensity } \frac{\text { weighof solids }}{\text { volumof solidsterovendryin }}
$$

Porosity or percentage pore space was determined using the ratio of bulk density to particle density (Brady, 1974; Lewis 1979) as follows:

$$
\text { Percen\% } \% \text { porespace }=\frac{100-\text { bulkdensity }}{\text { particlelensity }} \times 100
$$

The $\mathrm{pH}$ and conductivity of sediments were analyzed using the electrometric methods (Blake 1965a). Organic carbon was determined using Walkley and Black, 1934. Organic matter was determined using the formula:

$\%$ organic matter $=\%$ organic carbon $\times 1.724$

\section{RESULTS AND DISCUSSION}

Physicochemistry of Brackish Sediment

Soil $\mathrm{pH}$ : Soil $\mathrm{pH}$ in the four stations was acidic. Values obtained varied between $4.09 \pm 1.29$ in station II and $5.04 \pm 0.12$ in station I (Table 1 ). The acidity of mangrove soils are known to drop from near neutral when moist to less than four when oxidized (Dublin-Green and Ojanuga, 1988). Although the $\mathrm{pH}$ values obtained for the soils in the Andoni flats did not drop below 4.0; the values were close to four indicating acidity. The soils in station II were the most acidic.

Contrasting results were obtained in the Tendo Lagoon where $\mathrm{pH}$ of bottom sediment was near neutral (Sankare et al, 1997). Similarly, Smith (1996), reported near neutral $\mathrm{pH}$ of dried mangrove pond bottom sediments, he however reported that the pond side walls were often acidic; with acidity varying between 3.5 and 4.5.

Soil Organic Carbon and Organic matter and Water Absorbency: Mean values of organic carbon across stations all fell below 0.4 , except in station II where a high mean of $3.01 \%$ was recorded (Table 1). Correspondingly the range of organic matter of the sediments was between a low value of $0.29 \%$ and a high value of $5.22 \%$ in stations IV and II respectively. Mean values of less than $0.6 \%$ were obtained in stations I, III and IV. Water absorbency of dried soils in the Andoni flats varied between $21.74 \%$ (station IV) and $43.73 \%$ (station II). Mean values and standard deviations of water absorbency are outlined in Table 1. 
Table 1: Characteristics of sediment in the Andoni Flats

\begin{tabular}{lcccc}
\hline \multicolumn{1}{c}{ PARAMETERS } & \multicolumn{4}{c}{ STATIONS } \\
\cline { 2 - 4 } Soil pH & I & II & III & IV \\
\% Organic Carbon & $5.04 \pm 0.12$ & $4.09 \pm 1.29$ & $4.62 \pm 0.16$ & $4.50 \pm 0.14$ \\
\% Organic Matter & $0.35 \pm 0.32$ & $3.01 \pm 0.25$ & $0.325 \pm 0.04$ & $0.17 \pm 0.01$ \\
Conductivity $\mu \mathrm{S} / \mathrm{cm}$ & $0.595 \pm 0.54$ & $5.22 \pm 0.47$ & $0.56 \pm 0.06$ & $0.29 \pm 0.02$ \\
Water Absorbency (\%) & $1120 \pm 678.52$ & $1800 \pm$ & $1260 \pm 480.83$ & $1270 \pm$ \\
Particle Density $\left(\mathrm{g} \mathrm{cm}^{-3}\right)$ & $24.78 \pm 2.78$ & $43.73 \pm 5.29$ & $24.65 \pm 1.53$ & $21.74 \pm 1.29$ \\
Bulk Density $\left(\mathrm{g} \mathrm{cm}^{-3}\right)$ & 1.97 & 1.92 & 2.09 & 2.25 \\
Porosity (\%) & 29.19 & 0.46 & 1.36 & 1.41 \\
Sand (\%) & 95.10 & 76.0 & 35.0 & 37.33 \\
Silt $(\%)$ & 2.30 & 19.10 & 93.1 & 88.4 \\
Clay (\%) & 2.60 & 4.40 & 1.10 & 5.00 \\
\hline Textural Class & Sand & Loamy Sand & Sand & 6.60 \\
\hline
\end{tabular}

The high percentage of organic carbon and organic matter recorded in station II could primarily be attributed to input from the mangrove in form of dead leaves and decaying prop roots. Mann (1982) as well as Smith (1996) stated that organic enrichment of mangrove sediment in the intertidal zone is from leaf litter derived from mangrove trees and from detritus. Organic matter is known to affect other properties of soils (Brady, 1974). Station II which had the highest organic matter content had the highest water absorbency but the reverse was the case in stations I, III and IV which recorded low percentages of organic matter and correspondingly low values of water absorbency. This is an indication that soils in the intertidal zone with high organic matter will tend to retain more water at low tide when exposed to aerial conditions than soils with less organic matter. Water absorbency is synonymous with the water retention capacity of a soil. It indicates the volume of moisture that is retained by the sediment at the point of saturation. The high values of organic carbon in station II could allow for its being classified as an organic soil. However, the other stations cannot be classified as such since they have low organic carbon content.

Conductivity $(\mu \mathrm{S} / \mathrm{cm})$ : Conductivity of sediments varied between $1120 \mu \mathrm{S} / \mathrm{cm}$ in station I and $1800 \mu \mathrm{S} / \mathrm{cm}$ in station II. Mean values of conductivity in stations I, III and IV were relatively lower than in station II (Table 1).

The results for conductivity obtained for the sediment in the Andoni flats indicate that the sediments can be classified as saline since values obtained were above $1120 \mu \mathrm{S} \mathrm{cm}^{-1}$. Smith (1996) reported values of 12.6 $\mathrm{mS} \mathrm{cm}{ }^{-1}$ from mangrove sediment in the Clarence River; while Sikoki and Veen (2004), reported extremely low values of $3.8-10.0 \mu \mathrm{S} \mathrm{cm}^{-1}$ in the Shiroro Reservoir (fresh water), Nigeria. An inverse relationship between conductivity and $\mathrm{pH}$ was observed in the sediment of the Andoni flats. The sediment in station II that was most acidic (low pH) had the highest conductivity while sediment in station I which had the highest $\mathrm{pH}$ value recorded the lowest conductivity.

Particle Density, Bulk Density and Porosity: Particle density, bulk density and porosity of the sediments are shown in Table 1. Values show particle density varied between $1.92 \mathrm{gcm}^{-3}$ in station II and $2.25 \mathrm{gcm}^{-3}$ in station IV. For bulk density a low value of 0.46 $\mathrm{gcm}^{-3}$ was obtained in station II and the highest value, $1.41 \mathrm{gcm}^{-3}$ was obtained in station IV. Porosity or percent $(\%)$ pore space of the sediments varied between $29.19 \%$ in station I and a high value of $76 \%$ in station II. All other stations except station II recorded porosity values below $38 \%$.

Particle density of the sediment in the Andoni flats was observed to increase with an increase in bulk density; while porosity of the sediment increased with a decrease in bulk density. Characteristically, station II was different from all other stations by having the lowest bulk density $\left(0.46 \mathrm{~g} \mathrm{~cm}^{-3}\right)$ and a very high porosity $(79 \%)$. The high porosity ensured that more pore spaces were occupied by air and water when compared to the other sediment in stations I, III and IV. The low particle density in station II could be attributed to the high organic matter content of the soil, since organic matter weighs less than an equal volume of soil (Brady, 1974). On the contrary stations one, three and four which recorded high particle density had low organic matter content. As expected, an inverse relationship was observed 
between porosity and bulk density with the latter increasing as the former decreased.

Particle Size: The sediment in the study area had high sand content; above $75 \%$. Station II had highest per cent silt content of $19.1 \%$. All other stations recorded silt values below $7 \%$. Clay content was lowest in station I with a value of $2.6 \%$; while the highest value of percent clay $(6.6 \%)$ was recorded in station IV. The results obtained showed that stations I, III and IV were of the sand textural class; while station II was of the loamy sand textural class (Table 1). The Andoni flats are generally known for their mud/sand nature (Yoloye, 1976). From the present study, the particle size of sediment in the Andoni flats indicate that three-quarters (stations I, III and IV) of the soil is sandy while one-quarter (station II) could be classified as loamy sand or muddy sand soil. This confirms the report in Yoloye (1976), which indicated that the Andoni flats have a mud/sand nature.

In comparison, sediments in station II had the highest percentage of silt $(19.10 \%)$, while the other three stations had low percent silt. Station II is covered by mangrove vegetation and as such experiences restricted movement of tide and wave action due to the presence of vegetation. This provides a suitable habitat for the settling of sediments and detritus from the water column to the bottom and as such accumulation of silt fraction in that station. Similarly, Smith (1996) reported that soil samples from inland mangrove habitats in the Clarence River with restricted tidal movements had pronounced peaks in the silt fraction. Stations I and III though in the intertidal zone do not have any vegetation cover and have low percentages of silt $(\leq 2.30 \%)$ and high sand contents exceeding 93\%. This is expected as these stations are exposed to a higher tidal influence and wave action. Friedman and Sanders (1978) stated that wave action and tidal currents are enough to produce the development of sandy sediment in intertidal zones. Station IV in the subtidal zone also recorded high percentage of sand though less than what was obtained in stations I and III. However the highest clay content was observed in this station. It also recorded the second highest percentage of silt. This may be due to the fact that settling of silt is continuous since this station is always submerged.

Conclusion: The sediment characteristics of the Andoni are prone to changes which could arise from human activities such as removal of mangrove vegetation for domestic fuel, sand filling, expansion of water ways and pollution from hydrocarbons; these could lead to deleterious effects on the biological resources of the flats. This calls for adoption of management strategies geared towards the conservation and protection of the environment.

\section{REFERENCES}

Ajao, EA; Fagade, SO (2002). The benthic macrofauna of Lagos Lagoon. The Zoologist. Vol. 1 (2): $1-15$.

Akpan, ER (1999). Spatio-seasonal trends of physicochemical characteristics of Cross River Estuary, Nigeria. Halophyte uses in different climates I. pp 127-131.

Akpan ER; Offem, JO (1993). Seasonal variation in water quality of the Cross River, Nigeria. Rev. Hydrobiol. Trop. 26 (2): 95-103.

Akpan, ER; Ekpo, HE; Ekpe, UJ (2003). Seasonal variation in water quality of the Calabar River: influence of tidal and coastal activities. Global Journal of Environmental Sciences. 2(2): 106-110.

Barnes, RSK; Hughes, RN (1988). An introduction to marine ecology. 2nd edition. Blackwell Scientific Publications. 351p.

Blake, GR (1965 a). Particle density. In: Blake GR (Ed). Methods of soil Analysis, Part I. Physical and Mineralogical Properties. American Society of Agronomy Madison, pp 371 - 373.

Blake, GR (1965 b). Bulk density. In: Blake GR (Ed). Methods of soil Analysis, Part I. Physical and Mineralogical Properties. American Society of Agronomy Madison, pp 374 - 390.

Bouyoucos, GH (1951). A recalibration of the hydrometer for making mechanical analysis of soils. Agron. Journ 43: 434 - 438.

Brady, NC (1974). The nature and properties of soils. 8th Edition. Macmillan Publishing Co. Inc. New York. 639p.

Dublin-Green, CO; Ojanuga, AG (1988). The problem of acid sulfate soils in brackish water aquaculture: a preliminary study of the soils of NIOMR/ARAC fish farm, Buguma, Rivers State, Nigeria. NIOMR Tech. Pap. No. 45. 20pp.

Edokpayi, CA; Lawal, MO; Okwok, NA; Ogunwenmo, CA (2004). Physicochemical and macrobenthic faunal characteristics of Kuramo Water, Lagos, Southern Nigeria. African Journal of Aquatic Science. 
Ekeh, IB; Sikoki, FD (2003). The state and seasonal variability in some physicochemical parameters of the New Calabar River, Nigeria. Supp.ad Acta Hydrobiologica. 5, $45-60$.

Francis, A (2003). Studies on the ichthyofauna of the Andoni River system in the Niger Delta of Nigeria. PhD Thesis, University of Port Harcourt. 279p.

Friedman, GM; Sanders JE (Eds) 1978. Principles of sedimentology. John Wiley and Sons, Canada, $792 \mathrm{p}$.

Giovanni, MV; Goretti, E; Tamanti, V; Di-Giovanni, MV (1996). Macrobenthos in Montedoglio Reservoir, Italy. Hydrobiologia 321 (1): 17-28.

Lewis, DT (1979). Bulk density. In: Fairbridge, RW; Finkl, CW Jnr (Eds). The encyclopedia of soil science. Part 1. Physics, chemistry, biology, fertility and technology. Dowden, Hutchinson and Ross, PA, USA pp 47 -48.

Lie, U (1968). A quantitative study of benthic infauna in Puget Sound, Washington, USA in 1963 - 1964. Fish. Dir. Skr. Ser. HavUnders. 14 (5): 229 - 556.
Mann, KH (1982). Ecology of coastal waters, a systems approach. Studies in ecology; Vol. 8. Blackwell Scientific Publications. Oxford, London, Edinburgh, Boston, Melbourne. 322p.

Sankare, Y; Kodjo, E; Kouassi, N'G (1997). L'aquaculture en habitat artificiel (acadja-enclos): modifications et transformations du milieu lagunaire (lagune Tendo, Cote d'Ivoire). Vie Milieu. 47 (1): 25 - 32.

Sikoki, FD; Veen, JV (2004). Aspects of water quality and the potential for fish production of Shiroro Reservoir, Nigeria. Liv. Sys.Sus. Dev. 2, $7 \mathrm{pp}$.

Smith, PT (1996). Physical and chemical characteristics of sediments from prawn farms and mangrove habitats on the Clarence River, Australia.Aquaculture. 146: $47-83$.

Walkley, A; Black, IA (1934). An examination of the Degtjareff Method for determining soil organic matter and proposed modification of the chronic acid titration method. Soil Sci. 37: 29 - 38.

Yoloye, V (1976). The ecology of the West African bloody cockle, Anadara (Senilia) senilis (L.). Bulletin de l'I.F.A.N. T. 38, ser. A, n ${ }^{\circ}$ 1, 56p. 